\title{
ФУНКЦІОНАЛЬНИЙ СТАН СЕРЦЕВО-СУДИННОЇ СИСТЕМИ ЗА РЕЗУЛЬТАТАМИ ВЕЛОЕРГОМЕТРІЇ І ЛІПІДНИЙ СКЛАД КРОВІ У ХВОРИХ НА СТАБІЛЬНУ ІШЕМІЧНУ ХВОРОБУ СЕРЦЯ ЗАЛЕЖНО ВІД КІЛЬКОСТІ УРАЖЕНИХ КОРОНАРНИХ АРТЕРІЙ
}

\author{
๑І. Г. Купновицька, Н. М. Романишин \\ ДВНЗ «Івано-Франківський національний медичний університет»
}

PEЗЮМЕ. Серед кардіальної патології ішемічна хвороба серця (IXC) займає провідну позицію. Тривала ішемія міокарда, незалежно від соціально-економічного розвитку країни, $\epsilon$ причиною смертності та інвалідизації населення. Основними доведеними факторами ризику розвитку серцево-судинних захворювань $\epsilon$ гіпер- та дисліпідемія й абдомінальне ожиріння.

Мета - проаналізувати гемодинамічні та ергометричні показники серця за даними велоергометрії (ВЕМ), ліпідний склад крові та оцінити антропометричні дані у пацієнтів із стабільною IXС залежно від кількості уражених коронарних артерій (КА).

Матеріал і методи. У дослідженні взяли участь 62 хворих на стабільну IXC з стенокардією напруги функціонального класу (ФК) III із серцевою недостатністю (СН) ІІА ФК III із збереженою фракцією викиду лівого шлуночка (ФВ ЛШ). Серед обстежених переважали чоловіки - 52 особи (83,9 \%). Середній вік пацієнтів становив $(61,2 \pm 1,2)$ року. Клінічні групи поділені на підгрупи залежно від кількості уражених КА: у 16 (25,8 \%) хворих за даними коронароангіографії (КАГ) виявлено односудинне ураження, а в 46 (74,2 \%) пацієнтів - кількасудинне.

Результати. Доведено, що коронарний та міокардіальний резерви і скоротлива здатність міокарда за даними ВЕМ виявилися зниженими в обох підгрупах спостереження, проте вираженими ці зміни були у випадку ураження двох і більше КА (р<0,05). Антропометричні показники - індекс маси тіла (IMT) та обвід талії - перевищували нормативне значення у $42(67,7 \%)$ хворих (p<0,001), причому в пацієнтів із ураженням двох і більше КА ці зміни були більш виражені, ніж у пацієнтів з ураженою однією КА $(p<0,05)$.

Кількість холестерину загального (ХСЗ), тригліцеридів (ТГ), ХС ліпопротеїдів низької та високої щільності (ХС лПнЩ, ХС лПВЩ) в сироватці крові достовірно відрізнялися у обох групах пацієнтів $(p<0,05)$.

КЛючОВІ СлОВА: стенокардія напруги; коронарні артерії; фізичне навантаження; ліпіди; ожиріння.

Вступ. Однією з найважливіших медико-соціальних проблем в Україні $\epsilon$ зростання випадків серцево-судинних захворювань. Серед кардіальної патології ішемічна хвороба серця (IXC) займає провідну позицію. Тривала ішемія міокарда є причиною смертності та розвитку інвалідності населення незалежно від соціально-економічного розвитку країни [3]. Так, у Великобританії середня частота виникнення стенокардії складає 213 випадків на 100 тис. населення на рік, а у США поширеність IXC становить 3,7 \%. В Україні поширеність даного захворювання складає більше 5,7 \%, при цьому смертність від даної недуги у 3,5 раза переважає смертність у країнах Європейського Союзу, а для чоловіків віком 30-59 років та жінок віком 45-59 років - у 5 разів $[11,17]$.

Значний вплив на розвиток серцево-судинної патології в населення України має дисліпідемія [4, 9]. Стандартизоване обстеження населення показало, що поширеність гіперхолестеринемії становить $46 \%$ серед осіб чоловічої статі та $61 \%$ - жіночої, при цьому в $16 \%$ чоловіків та $18 \%$ жінок рівень холестерину загального (ХСЗ) перевищує 6,2 ммоль/л. Підвищений рівень тригліцеридів (ТГ) визначено у $11 \%$ чоловіків та $8 \%$ жінок. Зниження рівня XС ліпопротеїдів високої щільності (ЛПВЩ) виявлено у $27 \%$ чоловіків та $28 \%$ жінок $[5,10]$.
Особливу увагу слід приділити хворим на стабільну IXC із супутнім цукровим діабетом (ЦД). Оскільки IXC у хворих на ЦД може розглядатись як макроангіопатія коронарних судин, яка у своїй більшості $\epsilon$ наслідком прискореного атеросклерозу - атероматозного процесу, що розвивається раніше і прогресує швидше у таких хворих, порівняно з загальною популяцією $[6,7]$.

Коронарний атеросклероз у хворих на ЦД характеризується множинністю стенозів у проксимальній і дистальній частинах однієї і тієї ж судини, переважанням дрібних стенозів. Багатосудинне ураження коронарних артерій (КА) підтверджене численними дослідженнями [13], а також ретроспективним аналізом 1133 коронарограм хворих ЦД (порівняно з 9300 хворими без ЦД), яким була проведена перкутанна ангіопластика [16]. При цьому ангіографічно визначений колатеральний кровотік спостерігається тільки у 10,3 \% хворих на ЦД, в порівнянні з $41,5 \%$ у осіб без діабету, що може бути обумовлено наявністю специфічної мікроангіопатії, пошкодженням ендотелію і його нездатністю до виділення судинорозширювальних чинників, а також відсутністю достатнього градієнта перфузійного тиску на тлі превалювання дрібних звужень КА [13]. 
Огляди літератури, оригінальні дослідження, погляд на проблему, випадок з практики, короткі повідомлення

Відсутність адекватного колатерального кровотоку разом з прогресуючим атеросклерозом коронарних судин, визначеним за допомогою ангіографії, може бути причиною поганого прогнозу захворювання і гіршого виживання з частим розвитком серцевої недостатності (CH) та інфаркту міокарда (IM).

Незважаючи на бурхливий розвиток методів ангіографічної діагностики IXC та неінвазивних методів візуалізації міокарда, навантажувальні проби залишаються одним з найдоступніших методів скринінгового обстеження та діагностики цієї недуги, стратифікації ризику, оцінки функціонального стану пацієнтів й ефективності антиішемічної терапії. Толерантність до фізичного навантаження (ТФН) та ступінь реактивності серцевосудинної системи свідчать про якість життя хворого з IXC [14]. Тести із дозованим ФН, зокрема велоергометрія (ВЕМ), можуть дати додаткову інформацію, оскільки існує зв'язок між приростом частоти серцевих скорочень (ЧСС) під час ФН та серцево-судинними ускладненнями [12]. У такому випадку велоергометрична проба дозволяє перевірити реакцію артеріального тиску (АТ) і ЧСС на дозоване ФН та дати характеристику ТФН, процесів споживання кисню міокардом і міокардіальних резервів. Ці показники мають значення у загальній адаптації організму.

Основними доведеними факторами ризику розвитку серцево-судинних захворювань $\epsilon$ гіперта дисліпідемія, абдомінальне ожиріння, ЦД, стрес, куріння, вік $[1,2,18]$. Крім того, встановлений прямий кореляційний зв'язок між захворюваністю і смертністю від IXC, з одного боку, і рівнем холестерину ліпопротеїдів низької щільності (ХС лПНЩ) в сироватці крові - з іншого $[15,19]$.

Мета - проаналізувати гемодинамічні та ергометричні показники серця за даними ВЕМ, ліпідний склад крові та оцінити антропометричні дані у хворих на стабільну IXC й встановити взаємозв'язок між отриманими результатами залежно від кількості уражених КА.

Матеріал і методи дослідження. Об'єктом дослідження обрано 62 хворих на стабільну IXC: стенокардію напруги функціонального класу (ФК) III з СН IIA ФК III із збереженою фракцією викиду лівого шлуночка (ФВ ЛШ), котрі підлягають стентуванню КА. Дослідження проводили на базі К3 «Івано-Франківський обласний клінічний кардіологічний центр», центральної міської клінічної лікарні Івано-Франківська; диспансерне спостереження здійснювали в міських поліклініках. Серед обстежених переважали чоловіки - 52 особи (83,9 \%). Середній вік хворих становив $(61,2 \pm 1,2)$ роки. Артеріальну гіпертензію II - III стадій 2 ступеня діагностовано у 54 (87,1 \%) пацієнтів. Досягти цільо- вих рівнів АТ вдалося за допомогою прийому раміприлу в дозі 5-10 $(6,67 \pm 2,39)$ мг/добу в 39 (62,9 \%) обстежених та, за появи непродуктивного кашлю, що було розцінено як побічну дію даного гіпотензивного лікарського засобу, лозартану

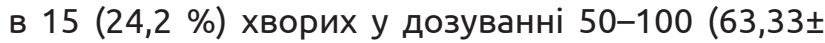
$22,89)$ мг/добу. Решта 8 (12,9\%) пацієнтів приймали раміприл у дозі 2,5 мг/добу. Окрім вищевказаних лікарських засобів пацієнти обох підгруп в однаковій кількості вживали [20] бісопролол у дозі 7,56士2,53 (5-10) мг/добу, препарати ацетилсаліцилової кислоти - 75 мг/добу, аторвастатин - 20$40(36,77 \pm 7,42)$ мг/добу. Хворі з ураженою однією КА додатково приймали нітрогліцерин у кількості $(11,81 \pm 0,35)$ таблеток на тиждень, а у випадку ураження двох і більше судин така потреба зростала до $(13,89 \pm 0,24)$ таблеток на тиждень. Перенесений в анамнезі і підтверджений документально інфаркт міокарда мали 27 (43,5 \%) хворих; на компенсований ЦД 2-го типу хворіли 7 (11,3 \%) пацієнтів, курили 49 (79,0 \%) хворих (5 - 10 цигарок на добу), нервово-емоційні стреси регулярно виникали у 43 (69,4 \%) обстежуваних. Причому, всі хворі на ЦД 2-го типу ввійшли в підгрупу пацієнтів із кількасудинним ураженням КА. Інші фактори ризику з однаковою частотою зустрічалися в обох підгрупах дослідження. Групу контролю норми склали 15 практично здорових осіб із збереженням гендерних і вікових пропорцій. Обстежувані були рандомізовані за кількістю уражених КА. За даними КАГ, у 16 (25,8 \%) хворих виявлено односудинне ураження КА, а у 46 (74,2 \%) пацієнтів спостерігали ураження двох і більше КА.

Коронароангіографію (КАГ) проводили за наявності згоди і при відсутності протипоказань усім хворим. Для даного дослідження використовували рентгенографічну ангіографічну систему Infinix CC-i/FPD виробництва Toshiba Medical Systems Corporation (Японія). Доступ до КА здійснювали через а. radialis; для контрастування судин використовували контрасти Ultravist 370 мг/мл, Omnipaque 350 мг/мл а6о Visipaque 320 мг/мл.

Хворим проводили клініко-лабораторне обстеження згідно з Уніфікованим клінічним протоколом надання медичної допомоги «Стабільна ішемічна хвороба серця» 02.03.2016 № 152 (зі змінами 23.09.2016 № 994), рекомендаціями Європейського кардіологічного товариства «ESC Guidelines for the diagnosis and treatment of acute and chronic heart failure 2012» та настановами Української асоціації фахівців із СН (2017).

ВЕМ проводили з метою верифікації ФК стабільної стенокардії та встановлення ТФН. Дослідження проводили на велоергометрі моделі «Кардіо+» МНДІ, 944150.001РЄ (Україна), вранці через 1,5-2 години після легкого сніданку та від- 
Огляди літератури, оригінальні дослідження, погляд на проблему, випадок з практики, короткі повідомлення сутності фактора куріння цигарок, при температурі повітря $18-20^{\circ} \mathrm{C}$ за східцеподібною методикою О. Й. Жарінова [8]. За дві доби до проведення проби були відмінені ß-адреноблокатори. Застосування антиангінальних препаратів дає можливість досягати більшої ТФН з меншою депресією сегмента ST та меншими проявами стенокардії [8]. Початковий рівень навантаження становив 25 Вт, з наступним збільшенням навантаження на 25 Вт кожні 3 хвилини зі швидкістю 60-80 обертів за хвилину до досягнення кінцевих точок. Критеріями припинення ВЕМ-тесту вважали досягнення субмаксимальної ЧСС, появу типового ангінозного нападу, депресію сегмента ST (горизонтальна або косонизхідна $\geq 1$ мм), елевацію сегмента ST $\geq 1$ мм у відведеннях без зубців Q (крім V1 і aVR), відчуття нестачі повітря, значну задишку, ядуху, відсутність підвищення систолічного АТ або його зниження $\geq 10$ мм рт. ст. при збільшенні потужності навантаження, яке супроводжується або не супроводжується ознаками ішемії міокарда; шлуночкову тахікардію, часту шлуночкову екстрасистолію, суправентрикулярну тахікардію, атріовентрикулярну блокаду 2 - 3 ступенів, брадіаритмію, блокаду ніжки пучка Гіса; підвищення систолічного АТ понад 230 мм рт. ст. і/а6о діастолічного АТ понад 115 мм рт. ст.; симптоми з боку центральної нервової системи (атаксія, запаморочення, передсинкопе); ознаки недостатньої периферійної перфузії (ціаноз, блідість, судоми в нижніх кінцівках, минуща кульгавість); значну слабкість, втому, прохання пацієнта зупинити навантажуваньну пробу.

Під час виконання ВЕМ-тесту реєстрацію ЕКГ здійснювали наприкінці кожної сходинки навантаження, не припиняючи педалювання. АТ вимірювали за 30 секунд до завершення педалювання встановленої потужності навантаження. Після проби здорові продовжували педалювання з малою потужністю протягом 1 - 2 хвилин з метою запобігання виникненню колапсу, спричиненого генералізованою периферійною вазодилатацією і різким зменшенням венозного повернення крові.

ТФН оцінювали за величиною порогової потужності. Пробу оцінювали як позитивну при горизонтальній депресії сегмента ST на 1 мм через інтервал 0,08 с від початкової точки у трьох послідовних комплексах одного з відведень ЕКГ. У стані спокою на кожній сходинці на граничному навантаженні у відновлювальний період вимірювали АТ та чСС.

Хронотропну функцію серця визначали за допомогою індексу хронотропного резерву (IXP, \%):

IXP = (ЧСС навант. - ЧСС спокою) $\times 100$ \% / ЧСС спокою.

Стан інотропної функції серця при ФН визначали за допомогою обчислення індексу інотропного резерву (IIP, \%):

IIP = (АТ сист. навант. - АТ сист. спокою $) \times 100 \% /$ АТ сист. спокою.

Низький приріст IIP вказує на зниження міокардіальних резервів.

Подвійний добуток (ПД) на кінцевому етапі ФН вираховували за формулою:

$$
\text { ПД = (ЧСС } \times \text { АТ сист.) } / 100 .
$$

ПД відображає споживання кисню міокардом, навантаження на серцево-судинну систему в різні періоди доби та при різному ФН. Існує лінійна залежність між споживанням кисню міокардом і коронарним кровотоком. При максимальному навантаженні коронарний кровотік збільшується у 5 разів, порівняно з вихідним. При обструктивному ураженні коронарних артерій здатність до підтримання коронарного кровотоку в ураженій ділянці та забезпечення метаболічних потреб міокарда під час навантаження втрачається, що спричиняє ішемію міокарда [8].

Продуктивність роботи лівого шлуночка (ПРЛШ) - показник, який відображає ЧСС залежно від потужності ФН:

ПРЛШ = потужність. навант. (ВТ) × 100 / ЧСС на конкретному етапі $Ф$ Н.

Функціональний клас стенокардії визначали згідно з рекомендаціями Канадського товариства кардіологів.

Визначення рівня ХСЗ та ТГ у сироватці крові проводили ферментативно-колометричним методом. Концентрацію ХС ЛПНЩ та лПВЩ у сироватці крові визначали прямим, без осадження, ферментативним методом. Ліпідний спектр крові досліджуваних визначали з використанням набору реагентів «ELITech» (France) на аналізаторі «GBC Stat Fax 4500» (USA). Величину коефіцієнта атерогенності вираховували за формулою (ХСЗ ХС лПВЩ) / ХС ЛПВЩ [21].

Для об'єктивної оцінки ступеня достовірності результатів дослідження застосовували варіаційно-статистичний метод аналізу отриманих результатів на персональному комп'ютері Pentium II із використанням пакета статистичних програм «Statistica 8.0» і пакета статистичних функцій «Microsoft Excel».

Результати й обговорення. Для визначення ФК стенокардії використовували ВЕМ з аналізом досягнутого навантаження, виконаної роботи, гемодинамічних та ергометричних показників. У всіх учасників тестування з навантаженням у 25 Вт завершилося без появи будь-яких скарг та ЕКГ-ознак ішемії. Відмічене помірне наростання рівнів систолічного АТ та ЧСС (табл. 1). Наступним етапом було продовження ВЕМ з навантаженням у 50 Вт. Проба 
Огляди літератури, оригінальні дослідження, погляд на проблему, випадок з практики, короткі повідомлення була позитивною у всіх з одно- та у 18 обстежуваних з кількасудинним ураженням КА, загалом у 34 (54,8 \%) хворих. Причому, пацієнтам з односудинним ураженням КА пробу припинили до завершення тестування (5 хворим наприкінці 2 хвилини і 11 хворим в другій половині 3 хвилини педалювання). У 3 хворих з ураженням двох і більше КА проба була розцінена як позитивна на середині проведення дослідження, причиною чого стала поява косонизхідної депресії сегмента ST $\geq 1$ мм за даними ЕКГ без виникнення больового синдрому, а у решти 15 хворих в першій половині 3 хвилини. Швидше виникнення типової ангінозної клінічної картини та ЕКГ-ознак ішемії у пацієнтів із багатосудинним ураженням КА пояснюється наявними факторами: швидким прогресуванням атеросклерозу у хворих на супутній ЦД 2-го типу з вираженою дис- та гіперхолестеринемією і порівняно вищим показником антропометричних даних, що, в свою чергу, спричинило нижчу ТФН.

Таблиця 1. Гемодинамічні показники при велоергометрії у хворих на стабільну IXC: стенокардію напруги ФК III з СН IIA ФК III із збереженою ФВ ЛШ (М士M)

\begin{tabular}{|c|c|c|c|}
\hline \multirow[b]{2}{*}{ Показники } & \multirow[b]{2}{*}{ Здорові, n=15 1} & \multicolumn{2}{|c|}{ Обстежувані, n = 62} \\
\hline & & $\begin{array}{c}\text { ураження } 1 \mathrm{KA}, \\
\mathrm{n}=16\end{array}$ & $\begin{array}{c}\text { ураження } 2 \text { і більше KA, } \\
\text { n=46 }\end{array}$ \\
\hline ЧСС, уд/хв (в стані спокою) & $68,13 \pm 2,07$ & $\begin{array}{c}77,25 \pm 2,52 \\
p_{1-2}<0,05\end{array}$ & $\begin{array}{l}78,13 \pm 2,93 \\
P_{1-3}<0,001 \\
P_{2-3}>0,05\end{array}$ \\
\hline $\begin{array}{l}\text { ЧСС, уд/хв (порогове фізичне } \\
\text { навантаження } 25 \text { Вт), протягом } 3 \text { хв }\end{array}$ & $98,27 \pm 3,45$ & $\begin{array}{c}112,50 \pm 4,53 \\
\mathrm{P}_{1-2}<0,05\end{array}$ & $\begin{array}{c}117,17 \pm 3,90 \\
P_{1-3}<0,001\end{array}$ \\
\hline $\begin{array}{l}\text { ЧСС, уд/хв (порогове фізичне } \\
\text { навантаження } 50 \text { Вт), протягом } 3 \text { хв }\end{array}$ & $134,13 \pm 3,42$ & $\begin{array}{c}120,63 \pm 3,56 \\
p_{1-2}<0,05\end{array}$ & $\begin{array}{c}117,92 \pm 3,07 \\
p_{1-3}<0,05\end{array}$ \\
\hline $\begin{array}{l}\text { Систолічний АТ, мм рт. ст. (в стані } \\
\text { спокою) }\end{array}$ & $120,67 \pm 2,58$ & $\begin{array}{c}139,69 \pm 3,40 \\
p_{1-2}<0,05\end{array}$ & $\begin{array}{c}140,90 \pm 3,04 \\
P_{1-3}<0,001 \\
P_{2-3}>0,05\end{array}$ \\
\hline $\begin{array}{l}\text { Систолічний АТ, мм рт. ст. (порогове } \\
\text { фізичне навантаження } 25 \text { Вт), } \\
\text { протягом } 3 \text { хв }\end{array}$ & $150,67 \pm 3,72$ & $157,81 \pm 3,63$ & $160,98 \pm 5,01$ \\
\hline $\begin{array}{l}\text { Систолічний АТ, мм рт. ст. (порогове } \\
\text { фізичне навантаження } 50 \text { Вт), } \\
\text { протягом } 3 \text { хв }\end{array}$ & $179,33 \pm 4,58$ & $\begin{array}{c}166,88 \pm 4,43 \\
p_{1-2}<0,05\end{array}$ & $\begin{array}{c}162,88 \pm 3,79 \\
p_{1-3}<0,05\end{array}$ \\
\hline
\end{tabular}

Незавершеною проба реєструвалася у 20 (32,3\%) пацієнтів у випадку ураження двох і більше КА, причиною чого стали дискомфорт і втома сідничних м'язів та мускулатури нижніх кінцівок, запаморочення, які виникали ще до досягнення розрахованої субмаксимальної ЧСС у першій половині тестування. Сумнівним тест виявився у 8 (12,9\%) хворих, у котрих проведення проби супроводжувалася атиповим больовим синдромом без ЕКГ-ознак ішемії після завершення проби. Причиною припинення тесту найчастіше була депресія сегмента ST, що супроводжувалася больовим синдромом і відчуттям стиснення за грудниною.

Показники ЧСС та систолічного АТ у стані спокою в досліджуваних підгрупах пацієнтів практично не відрізнялися між собою ( $>>0,05)$.

При зростаючому динамічному навантаженні рівень систолічного АТ підвищувався, тоді як рівень діастолічного АТ залишався незмінним або дещо підвищувався (до 10 мм рт. ст.). Різкого зниження рівнів діастолічного АТ, або неадекватного підвищення систолічного АТ (менш ніж на 20-
30 мм рт. ст.) чи його зниження на висоті навантаження, що $є$ прогностично несприятливим, за період проведення проби не відмічено.

При виконанні навантаження у 50 Вт у пацієнтів з кількасудинним ураженням КА на фоні вже порівняно незначного підвищення рівнів АТ та ЧСС стало різко погіршуватися самопочуття, що супроводжувалося дестабілізацією стану. Це підтверджувалося результатами навантажувального тесту, про що свідчить зменшення часу виконання тесту хворими з ураженням двох і більше КА та найнижчої ТФН порівняно з іншими обстежуваними.

Аналіз гемодинамічних показників дав змогу виявити певні особливості. Порогова ЧСС у підгрупі пацієнтів з кількасудинним ураженням КА була нижчою, порівняно з хворими із ураженням однієї KA ( $p>0,05)$. Отже, якщо здорові на 2 сходинки навантаження відреагували збільшенням ЧСС майже вдвічі $(p<0,05)$, то пацієнти з ураженням однієї і двох та більше КА - в 1,56 та 1,51 раза відповідно $(p<0,05)$. Зміни систолічного АТ на на- 
Огляди літератури, оригінальні дослідження, погляд на проблему, випадок з практики, короткі повідомлення вантаження були аналогічними: зростання АТ у здорових у 1,49 раза ( $<<0,05)$, у хворих на IXC - В 1,19 та 1,16 раза $(p<0,05)$.

Таким чином, і чСС, і АТ були найнижчими в пацієнтів із кількасудинним ураженням КА $(p<0,05)$. Тому ПД був вірогідно нижчим у хворих 3 кількасудинним ураженням КА, що свідчить про меншу ТФН хворих даної групи і про більшу потребу міокарда в кисні.

У пацієнтів з кількасудинним ураженням КА було виражене порушення функціональної здатності міокарда, що проявляється зниженням міо-

кардіальних резервів. Виконання одинакового об'єму роботи у таких хворих супроводжувалося більшою потребою міокарда в кисні і стало причиною припинення тесту на перших двох хвилинах навантаження внаслідок появи типових скарг та ЕКГ-ознак ішемії, що свідчить про зниження можливостей міокардіальних резервів.

Ергометричний показник IIP, що відображає скоротливу здатність міокарда, при здійсненні кінцевого навантаження у 50 Вт був найнижчим у пацієнтів 3 багатосудинним ураженням KA (табл. 2).

Таблиця 2. Гемодинамічні та ергометричні показники при велоергометрії у хворих на стабільну IXC: стенокардію

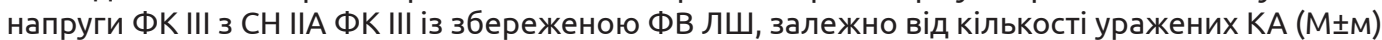

\begin{tabular}{|c|c|c|c|}
\hline \multirow[b]{2}{*}{ Показники } & \multirow[b]{2}{*}{ Здорові, n=15 } & \multicolumn{2}{|c|}{ Обстежувані, n=62 } \\
\hline & & $\begin{array}{c}\text { ураження } 1 \mathrm{KA}, \\
\mathrm{n}=16\end{array}$ & $\begin{array}{c}\text { ураження } 2 \text { і більше КА, } \\
\mathrm{n}=46\end{array}$ \\
\hline IXP, \% & $96,87 \pm 4,16$ & $\begin{array}{c}56,13 \pm 2,06 \\
\mathrm{P}_{1-2}<0,001 \\
\end{array}$ & $\begin{array}{c}50,08 \pm 3,40 \\
\mathrm{P}_{1-3}<0,001 \\
\end{array}$ \\
\hline IIP, \% & $48,20 \pm 2,34$ & $\begin{array}{l}19,25 \pm 3,71 \\
\mathrm{P}_{1-2}<0,001\end{array}$ & $\begin{array}{l}15,50 \pm 1,94 \\
p_{1-3}<0,001\end{array}$ \\
\hline ПД, \% & $240,13 \pm 5,69$ & $\begin{array}{c}201,44 \pm 7,69 \\
P_{1-2}<0,05\end{array}$ & $\begin{array}{c}191,96 \pm 6,36 \\
P_{1-3}<0,001\end{array}$ \\
\hline ПРЛШ, \% 25 Вт & $25,40 \pm 0,99$ & $\begin{array}{c}22,13 \pm 1,09 \\
P_{1-2}<0,05\end{array}$ & $\begin{array}{c}21,33 \pm 0,84 \\
P_{1-3}<0,05 \\
P_{2-3}>0,05\end{array}$ \\
\hline
\end{tabular}

Хронотропна й інотропна функції серця за показниками були найнижчими у пацієнтів з багатосудинним ураженням ( $<<0,001)$, але достовірно не відрізнялися між собою залежно від кількості уражених судин. Причому, у випадку кількасудинного ураження КА підвищення рівнів систолічного АТ та чСС спричиняло виникнення стенокардитичного нападу раніше, порівняно з іншими обстежуваними. Все це свідчить про низьку ТФН та зниження міокардіальних резервів, на що вказують величини ПД та ПРлШ.

Показник порогового ПД відповідав ІІІ ФК стенокардії, був вірогідно нижчим в обох підгрупах пацієнтів, але при багатосудинному ураженні КА відзначалася тенденція до менших його значень.

ПРЛШ вираховували при навантаженні 25 Вт, що пояснюється тим, що лише на цьому етапі тесту хворі обох підгруп пройшли пробу до кінця. За показниками навантажувального тесту ПРлШ була найнижчою у пацієнтів з ураженням двох і більше KA (p<0,05), порівняно із здоровими, але невірогідно нижчою, ніж у пацієнтів з ураженою однією КА.

При оцінці антропометричних даних IMT у

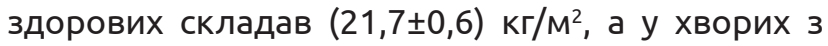

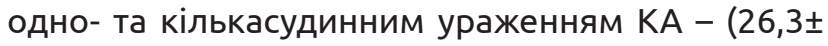

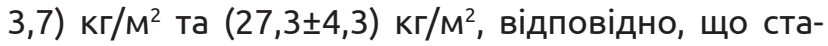
тистично значимо.
Тобто, нормальну масу тіла мали 20 (32,3 \%) обстежених, з котрих 5 (8,1\%) з одно- та 15 (24,2 \%) з ураженням двох і більше коронарних судин. Передожиріння (гладкість) виявлено у 8 (12,9\%) та 19 (30,6 \%) пацієнтів відповідно. Аліментарно-конституційне ожиріння І ст. діагностоване у 15 (24,2 \%) хворих, з котрих у 3 (4,8 \%) з ураженням однієї та у $12(19,4 \%)$ із ураженням двох та більше КА.

Аналогічні зміни стосуються обводу талії, яка у здорових становила $(83,2 \pm 1,0)$ см; у хворих з ураженням однієї КА $(93,1 \pm 4,4)$ см, а в обстежених 3 кількасудинним ураженням $(98,8 \pm 2,3)$ см. Отже, показник обводу талії на 11,9 \% і 18,7 \% перевищував показник здорових $(p<0,05)$, відповідно, залежно від ураження однієї чи кількох КА. У хворих з ураженням однієї КА обвід талії був на 5,9 \% меншим, ніж у хворих з ураженням двох і більше КА ( $>>0,05)$.

Зміни в ліпідному складі крові в пацієнтів обох порівнюваних підгруп були неоднозначними (табл. 3).

Рівень ХСЗ в пацієнтів у разі односудинного ураження перевищував нормативні значення у 1,4 раза $(p<0,001)$, а при ураженні кількох KA - у 1,5 раза ( $<<0,001)$, тобто у випадку багатосудинного ураження кількість ХСЗ на 4,6 \% тенденційно невірогідно була більшою, ніж при ураженні однієї КА. 
Огляди літератури, оригінальні дослідження, погляд на проблему, випадок з практики, короткі повідомлення

Таблиця 3. Ліпідний склад крові хворих на стабільну IXC: стенокардію напруги ФК III з СН IIA ФК III із збереженою ФВ ЛШ, (M士M)

\begin{tabular}{|c|c|c|c|}
\hline \multirow[b]{2}{*}{ Показники } & \multirow[b]{2}{*}{ Здорові, n=15 } & \multicolumn{2}{|c|}{ Обстежувані, n=62 } \\
\hline & & $\begin{array}{c}\text { ураження } 1 \mathrm{KA}, \\
\mathrm{n}=16\end{array}$ & $\begin{array}{c}\text { ураження } 2 \text { і більше КА, } \\
\text { n=46 }\end{array}$ \\
\hline ХСЗ, ммоль/л & $4,22 \pm 0,19$ & $\begin{array}{l}5,93 \pm 0,15 \\
\mathrm{P}_{1-2}<0,001\end{array}$ & $\begin{array}{l}6,20 \pm 0,33 \\
\mathrm{p}_{1-3}<0,001 \\
\end{array}$ \\
\hline ТГ, ммоль/л & $1,35 \pm 0,09$ & $\begin{array}{l}2,54 \pm 0,10 \\
P_{1-2}<0,001\end{array}$ & $\begin{array}{l}2,67 \pm 0,14 \\
P_{1-3}<0,001\end{array}$ \\
\hline ХС лПнЩ, ммоль/л & $2,47 \pm 0,08$ & $\begin{array}{l}4,25 \pm 0,32 \\
\mathrm{P}_{1-2}<0,001\end{array}$ & $\begin{array}{l}4,55 \pm 0,10 \\
P_{1-3}<0,001\end{array}$ \\
\hline ХС лПВЩ, ммоль/л & $1,35 \pm 0,05$ & $\begin{array}{l}0,86 \pm 0,04 \\
\mathrm{P}_{1-2}<0,001\end{array}$ & $\begin{array}{l}0,76 \pm 0,05 \\
P_{1-3}<0,001\end{array}$ \\
\hline $\begin{array}{l}\text { Коефіцієнт } \\
\text { атерогенності }\end{array}$ & $2,15 \pm 0,11$ & $\begin{array}{l}5,86 \pm 0,26 \\
p_{1-2}<0,001\end{array}$ & $\begin{array}{l}7,15 \pm 0,36 \\
p_{1-3}<0,001\end{array}$ \\
\hline
\end{tabular}

Рівень ТГ в крові у пацієнтів обох досліджуваних підгрупах з ураженням однієї КА у 1,9 раза перевищував значення норми, а у випадку багатосудинного ураження - у 2,0 раза ( $<<0,001)$, але при порівнянні показників між собою рівень ТГ в сироватці крові у пацієнтів з ураженням двох і більше КА був недостовірно вищим на 5,1\%.

Проаналізувавши ліпопротеїдний склад сироватки крові пацієнтів установили, що нормативні величини ХС ЛПнЩу пацієнтів були перевищені у 1,7 раза при ураженні однієї КА та в 1,8 раза при ураженні кількох KA $(p<0,001)$. При ураженні двох і більше КА цей показник на 7,0 \% відрізнявся від показника хворих, у яких була уражена одна КА $(p>0,05)$.

Рівень ХС ЛПВЩ у хворих обох підгруп був меншим, ніж у групі здорових, у 1,6 і 1,8 раза, відповідно до кількості уражених КА $(p<0,001)$. У па-

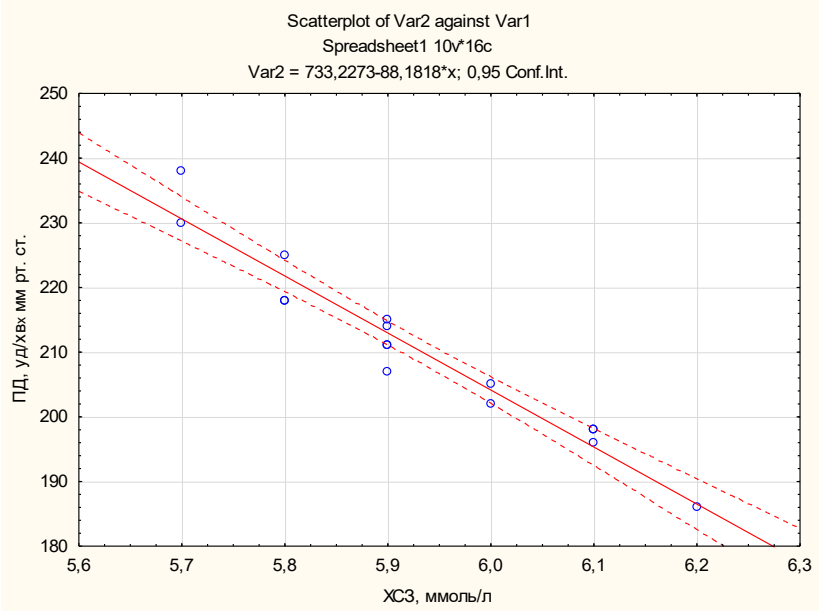

Рис. 1. Кореляційна залежність між подвійним добутком та кількістю холестерину загального у пацієнтів з односудинним ураженням коронарних артерій. цієнтів з ураженням однієї КА показник ХС лпВщ був на 11,6 \% вищим, ніж у пацієнтів з багатосудинним ураженням (p>0,05).

Коефіцієнт атерогенності перевищував показник норми при односудинному ураженні в 2,7 раза, при багатосудинному - в 3,3 раза $(p<0,001)$. Різниця між коефіцієнтами атерогенності обох клінічних підгруп становила 22,0% ( $<<0,01)$.

У результаті аналізу ліпідного складу крові пацієнтів обох досліджуваних підгруп ми встановили, що у них рівні ХСЗ, ТГ, ХС ЛПНЩ та коефіцієнт атерогенності $\epsilon$ достовірно вищими, ніж у здорових. Коефіцієнт атерогенності виявився достовірно вищим у хворих із багатосудинним ураженням КА. 3 огляду на отриманий результат можна стверджувати, що величина рівня показників ліпідограми чітко корелює із кількістю уражених коронарних судин (рис. 1, 2).

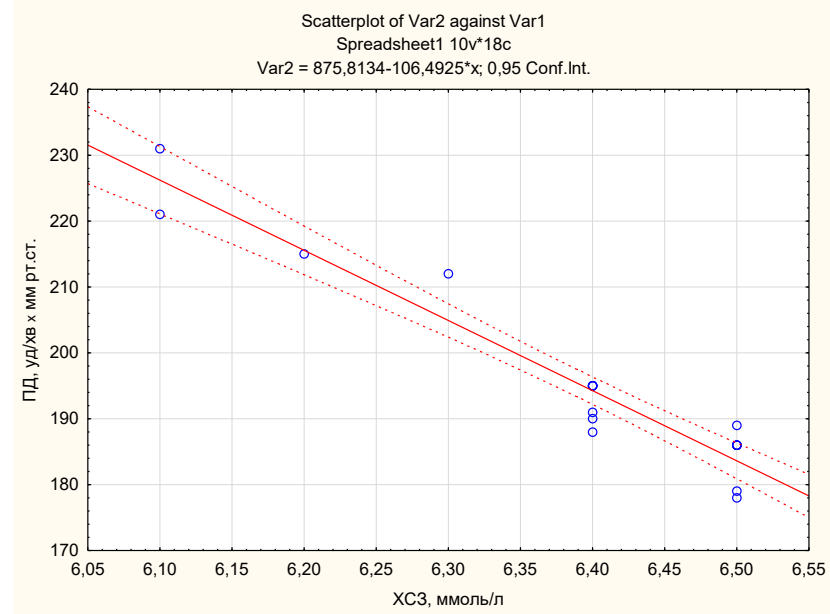

Рис. 2. Кореляційна залежність між подвійним добутком та кількістю холестерину загального у пацієнтів з кількасудинним ураженням коронарних артерій. 
Огляди літератури, оригінальні дослідження, погляд на проблему, випадок з практики, короткі повідомлення

Висновки. 1. У хворих на стабільну IXC: стенокардію напруги ФК III з СН IIA ФК III із збереженою ФВ ЛШ коронарний та міокардіальний резерви і скоротлива здатність міокарда за даними ВЕМ знижені більше у разі ураження двох і більше КА. У пацієнтів з багатосудинним ураженням виконання фізичного навантаження $\epsilon$ менш економним за показником гемодинамічного забезпечення, що підтверджується приростом ЧСС та більшою потребою міокарда в кисні на одиницю виконаної роботи.

\section{ЛІТЕРАТУРА}

1. Афанасюк О. І. Корекція порушень ліпідного обміну у хворих із стабільною стенокардією з коморбідним цукровим діабетом типу 2 / О. І. Афанасюк // Сімейна медицина. - 2014. - № 2 (52). - С. 67-69.

2. Вербовой А. Ф. Ожирение и сердечно-сосудистая система / А. Ф. Вербовой, А. В. Пашенцева, Л. А. Шарнова // Клиническая медицина. - 2017. - № 95 (1). С. 31-35.

3. Гандзюк В. А. Аналіз захворюваності на ішемічну хворобу серця в Україні / В. А. Гандзюк // Український кардіологічний журнал. - 2014. - № 3. - С. 45-52.

4. Горбась І. М. Дисліпідемії: епідеміологічний погляд / І. М. Горбась // Практична ангіологія. - 2011. № $(40)$. - C. 28-31.

5. Поширеність факторів ризику серцево-судинних захворювань в Україні: сучасний погляд на проблему / Д. Д. Дячук, Г. З. Мороз, І. М. Гідзинська, Т. С. Ласиця // Український кардіологічний журнал. - 2018. - № 1. С. $91-100$.

6. Ефимов А. Диабетическая невропатия / А. Ефимов, Н. Скробонская, Н. Зуєва // Ліки України. - 2005. № 3. - С. 21-25.

7. Ефимов А. С. Клиническая диабетология / А. С. Ефимов, Н. А. Скробонская. - К. : Здоров'я. - 1998. - 320 с.

8. Жарінов О. Й. Навантажувальні проби в кардіології / О. Й. Жарінов, В. О. Куць, Н. В. Тхор. - К. : Медицина світу. - 2006. - 89 с.

9. Динаміка структури ліпідного фактора серцевосудинного ризику протягом 35 років у міській популяції чоловіків / О. О. Кваша, І. П. Смирнова, І. М. Горбась, О. В. Срібна // Український кардіологічний журнал. 2016. - № 2. - С. 54-60.

10. Кириченко А. А. Стабильная стенокардия напряжения : оценка прогноза и лечение / А. А. Кириченко // Русский медицинский журнал. - 2014. - № 2. С. $106-110$.

11. Морозюк О. М. Визначення ергометричних показників проби з фізичним навантаженням у залізничників із серцево-судинними захворюваннями під час цільових медоглядів / О. М. Морозюк, С. І. Гречко, Л. П. Швець // Медицина транспорту України. - 2010. № 2. - С. 46-49.
2. Показники маси тіла IMT та обвід талії у всіх пацієнтів перевищують нормативні значення $(p<0,001)$ і $\epsilon$ більшими у хворих з ураженням двох і більше KA.

3. Число уражених КА залежить від ступеня дисліпідемії у хворих на стабільну IXC зі стенокардією напруги ФК III із СН IIA ФК III із збереженою ФВ ЛШ. Коефіцієнт атерогенності і $\epsilon$ достовірно вищим у хворих з багатосудинним ураженням KA $(p<0,05)$.
12. Несукай О. Г. Особливості добового профілю артеріального тиску та толерантності до фізичного навантаження у пацієнтів з гіпертонічною хворобою та в поєднанні з ішемічною хворобою серця / О. Г. Несукай, Н. В. Довганич // Український кардіологічний журнал. 2009. - № 4. - С. 45-49.

13. Соколов Е. І. Пошкодження міокарду і судин при цукровому діабеті / Е. І. Соколов // Терапевтичний архів. - 2005. - № 12. - С. 9-13.

14. Стародубова А. В. Ожирение как фактор риска сердечно-сосудистых заболеваний. Обзор литературы / А. В. Стародубова, О. А. Кисляк // Фарматека. - 2015. № 17. - С. 28-34.

15. Яковлева Л. М. Фактори, які асоціюються з підвищеним ризиком несприятливих серцево-судинних подій у хворих на ішемічну хворобу серця з верифікованим атеросклерозом коронарних артерій за тривалого спостереження / Л. М. Яковлева, В.И.Целуйко // Серце і судини. - 2014. - № 1. - С. 47-54.

16. Duchen L. W. Pathology of autonomic neuropathy in diabetes mellitus / L. W. Duchen, A. Anjorin // Ann. Intern. Med. - 1980. - Vol. 92. - P. 301-303.

17. Body mass index, lipid metabolism and estrogens: their impact on coronary heart disease / G. D. Kolovou, V. Kolovou P. M. Kostakou, S. Mavrogeni // Curr. Med. Chem. - 2014. - Vol. 21 (30). - P. 3455-3465.

18. Cifkova R. Dyslipidemia and cardiovascular disease in women / R. Cifkova, A. Krajcoviechova // Curr. Cardiol. Rep. - 2015. - Vol. 17 (7). - P. 609-611.

19. Lipoprotein subfractions partly mediate the association between serum uric acid and coronary artery disease / Y. Zhang, R. X. Xu, S. Li [et al.] // Clin. Chim. Acta. 2015. - Vol. 441. - P. 109-114.

20. HPLC method development for the analysis of bisoprolol in combined dosage form containing bisoprolol and enalapril and in vitro dissolution studied / L. Logoyda, S. Kovalenko, A. M. Abdel-Megied [et al.] // Int. J. App. Pharm. - 2019. - Vol 11, Issue 3. - P. 186-194. DOI https:// doi.org/10.22159/ijap.2019v11i3.32391

21. Zhulkevich I. V. Algorithm for phenotyping hyperlipoproteinemias and its application to the" Elektronika BZ-21" microcalculator / I. V. Zhulkevich, S. G. Vainshtein // Laboratornoe delo. - 1986. - Issue 10. - P. 623-625. 
Огляди літератури, оригінальні дослідження, погляд на проблему, випадок з практики, короткі повідомлення REFERENCES

1. Afanasiuk, O.I. (2014). Korektsiia porushen lipidnoho obminu u khvorykh iz stabilnoiu stenokardiieiu z komorbidnym tsukrovym diabetom typu 2 [Correction of lipid metabolism disorders in patients with stable angina with comorbid diabetes type 2]. Simeina medytsyna - Family Medicine, 2 (52), 67-69 [in Ukrainian].

2. Verbovoy, A.F., Pashentseva, A.V., \& Sharonova, L.A. (2017). Ozhireniye i serdechno-sosudistaya sistema [Obesity and the circulatory system]. Klinicheskaya meditsina Clinical Medicine, 95 (1), 31-35 [in Russian].

3. Handziuk, V.A. (2014). Analiz zakhvoriuvanosti na ishemichnu khvorobu sertsia v Ukraini [Analysis of incidence of coronary heart disease in Ukraine.]. Ukrainskyi kardiolohichnyi zhurnal - Ukrainian Cardiology Journal, 3, 45-52 [in Ukrainian].

4. Horbas, I.M. (2011). Dyslipidemii: epidemiolohichnyi pohliad [Dyslipidemias: an epidemiological perspective]. Praktychna anhiolohiia - Practical Angiology, 1 (40), 28-31 [in Ukrainian].

5. Diachuk, D.D., Moroz, H.Z., Hidzynska, I.M., \& Lasytsia, T.S. (2018). Poshyrenist faktoriv ryzyku sertsevo-sudynnykh zakhvoriuvan v Ukraini: suchasnyi pohliad na problemu [Prevalence of risk factors for cardiovascular disease in Ukraine: a modern perspective on the problem]. Ukrainskyi kardiolohichnyi zhurnal - Ukrainian Cardiology Journal, 1, 91-100 [in Ukrainian].

6. Yefimov, A., Skrobonskaya, N., \& Zueva, N. (2005). Diabeticheskaya nevropatiya [Diabetic neuropathy]. Liky Ukrainy - Medicines of Ukraine, 3, 21-25 [in Russian].

7. Yefimov, A.S., \& Skrobonskaya, N.A. (1998). Klinicheskaya diabetologiya [Clinical Diabetology]. Kyiv: Zdorovia [in Russian].

8. Zharinov, O.Y., Kuts, V.O., \& Tkhor, N.V. (2006). Navantazhuvalni proby $v$ kardiolohii [Load tests in cardiology]. Kyiv: Medytsyna svitu [in Ukrainian].

9. Kvasha, O.O., Smyrnova, I.P., Horbas, I.M., \& Sribna, O.V. (2016). Dynamika struktury lipidnoho faktora sertsevo-sudynnoho ryzyku protiahom 35 rokiv u miskii populiatsii cholovikiv [Dynamics of structure of lipid factor of cardiovascular risk for 35 years in urban population of men.]. Ukrainskyi kardiolohichnyi zhurnal - Ukrainian Cardiology Journal, 2, 54-60 [in Ukrainian].

10. Kirichenko, A.A. (2014). Stabilnaya stenokardiya napryazheniya: otsenka prognoza i lecheniye [Stable angina pectoris: prognosis assessment and treatment]. Russkiy meditsinskiy zhurnal - Russian Medical Journal, 2, 106-110 [in Russian].

11. Morozyuk, O.M., Hrechko, S.I., \& Shvets, L.P. (2010). Vyznachennia erhometrychnykh pokaznykiv proby z fizychnym navantazhenniam u zaliznychnykiv iz sertsevo-sudynnymy zakhvoriuvanniamy pid chas tsilovykh medohliadiv [Determination of the ergometric indices of the physical load test in the railway with cardiovascular diseases during

the targeted medical examinations]. Medytsyna transportu Ukrainy-Medicine of Transport of Ukraine, 2, 46-49 [in Ukrainian].

12. Nesukay, O.H., \& Dovhanych, N.V. (2009). Osoblyvosti dobovoho profiliu arterialnoho tysku ta tolerantnosti do fizychnoho navantazhennia u patsiientiv z hipertonichnoiu khvoroboiu ta v poiednanni $z$ ishemichnoiu khvoroboiu sertsia [Features of daily blood pressure profile and exercise tolerance in patients with hypertension and in combination with coronary heart disease]. Ukrainskyi kardiolohichnyi zhurnal - Ukrainian Cardiology Journal, 4, 45-49 [in Ukrainian].

13. Sokolov, E.I. (2005). Poshkodzhennia miokardu i sudyn pry tsukrovomu diabeti [Damage to the myocardium and blood vessels in diabetes]. Terapevtychnyi arkhiv Therapeutic Archive, 12, 9-13 [in Ukrainian].

14. Starodubova, A.V., \& Kislyak, O.A. (2015). Ozhireniye kak faktor riska serdechno-sosudistykh zabolevaniy. Obzor literatury [Obesity as a risk factor for cardiovascular disease. Literature review]. Farmateka - Farmateka, 17, 2834 [in Ukrainian].

15. Yakovleva, L.M., \& Tseluiko, V.Y. (2014). Faktory, yaki asotsiiuiutsia z pidvyshchenym ryzykom nespryiatlyvykh sertsevo-sudynnykh podii u khvorykh na ishemichnu khvorobu sertsia $z$ veryfikovanym aterosklerozom koronarnykh arterii za tryvaloho sposterezhennia [Factors associated with an increased risk of adverse cardiovascular events in patients with coronary artery disease with verified coronary atherosclerosis with long-term follow-up]. Sertse i sudynyHeart and Blood Vessels, 1, 47-54 [in Ukrainian].

16. Duchen, L.W., \& Anjorin, A. (1980). Pathology of autonomic neuropathy in diabetes mellitus. Ann. Intern. Med., 92, 301-303.

17. Kolovou, G.D., Kolovou, V., Kostakou, P.M., \& Mavrogeni, S. (2014). Body mass index, lipid metabolism and estrogens: their impact on coronary heart disease. Curr. Med. Chem., 21 (30), 3455-3465.

18. Cifkova, R., \& Krajcoviechova, A. (2015). Dyslipidemia and cardiovascular disease in women. Curr. Cardiol. Rep., 17 (7), 609-611.

19. Zhang, Y., Xu., R.X., Li, S., Zhu, C.G., Guo, Y.L., Sun, J., \& Li, J.J. (2015). Lipoprotein subfractions partly mediate the association between serum uric acid and coronary artery disease. Clin. Chim. Acta., 441, 109-114.

20. Logoyda, L., Kovalenko, S., Abdel-Megied, A.M., Zhulkevych, I., Drapak, I., Demchuk, I., \& Netsyuk, O. (2019). HPLC method development for the analysis of bisoprolol in combined dosage form containing bisoprolol and enalapril and in vitro dissolution studied. Int. J. App. Pharm., 11 (3), 186194. DOI https://doi.org/10.22159/ijap.2019v11i3.32391.

21. Zhulkevich, I.V., \& Vainshtein, S.G. (1986). Algorithm for phenotyping hyperlipoproteinemias and its application to the" Elektronika BZ-21" microcalculator. Laboratornoe delo, 10, 623-625. 


\title{
ФУНКЦИОНАЛЬНОЕ СОСТОЯНИЕ СЕРДЕЧНО-СОСУДИСТОЙ СИСТЕМЫ ПО РЕЗУЛЬТАТАМ ВЕЛОЭРГОМЕТРИИ И ЛИПИДНЫЙ СОСТАВ КРОВИ У БОЛЬНЫХ СТАБИЛЬНОЙ ИШЕМИЧЕСКОЙ БОЛЕЗНЬЮ СЕРДЦА В ЗАВИСИМОСТИ ОТ КОЛИЧЕСТВА ПОРАЖЕННЫХ КОРОНАРНЫХ АРТЕРИЙ
}

\section{○И. Г. Купновицкая, Н. Н. Романишин}

\author{
ГВУз «Ивано-Франковский национальный медицинский университет»
}

РЕЗЮМЕ. Среди кардиальной патологии ишемическая болезнь сердца (ИБС) занимает ведущую позицию. Длительная ишемия миокарда является причиной смертности и инвалидизации населения независимо от социально-экономического развития страны. Основными доказанными факторами риска развития сердечно-сосудистых заболеваний являются гипер- и дислипидемия и абдоминальное ожирение.

Цель - проанализировать гемодинамические и эргометрические показатели сердца по данным велоэргометрии (ВЭМ), липидный состав крови и оценить антропометрические данные пациентов со стабильной ИБС в зависимости от количества пораженных коронарных артерий (КА).

Материал и методы. В исследовании приняли участие 62 больных стабильной ИБС со стенокардией напряжения функционального класса (ФК) III с сердечной недостаточностью (СН) IIA ФК III с сохраненной фракцией выброса левого желудочка (ФВ лЖ). Среди обследованных преобладали мужчины - 52 человека (83,9 \%). Средний возраст пациентов составил 61,2 11,2 года. Клинические группы поделены на подгруппы в зависимости от количества пораженных КА: у 16 (25,8 \%) больных по данным коронароангиографии (КАГ) обнаружено однососудистое поражение, а у 46 (74,2 \%) пациентов - многососудистое.

Результаты. Доказано, что коронарный и миокардиальный резервы и сократительная способность миокарда по данным ВЭМ были сниженными в обеих подгруппах наблюдения, однако выраженными такие изменения наблюдались в случае поражения двух и более КА ( $<<0,05)$.

Антропометрические показатели - индекс массы тела (ИМТ) и окружность талии - превышали нормативное значение у $42(67,7$ \%) больных ( $<<0,001)$, причем у пациентов с многососудистом поражением КА эти изменения были более выражены, чем у пациентов с пораженной одной KA $(p<0,05)$.

Количество холестерина общего (ХСЗ), триглицеридов (ТГ), ХС липопротеидов низкой и высокой плотности (ХС ЛПНП, ХС ЛПВП) в сыворотке крови достоверно отличалось в обеих группах пациентов $(p<0,05)$.

КЛЮчЕВЫЕ СЛОВА: стенокардия напряжения; коронарные артерии; физическая нагрузка; липиды; ожирение.

\section{FUNCTIONAL STATE OF THE CARDIOVASCULAR SYSTEM ACCORDING TO THE RESULTS OF BICYCLE ERGOMETRY AND LIPID BLOOD COMPOSITION IN PATIENTS WITH STABLE CORONARY ARTERY DISEASE DEPENDING ON THE NUMBER OF AFFECTED CORONARY ARTERIES}

\author{
@I. G. Kupnovytska, N. M. Romanyshyn \\ Ivano-Frankivsk National Medical University
}

SUMMARY. Ischemic heart disease (IHD) occupies a leading position in cardiac pathology. Prolonged myocardial ischemia is the cause of mortality and disability of the population, regardless of the socio-economic development of the country. The main proven risk factors for cardiovascular disease are hyper- and dyslipidemia and abdominal obesity.

The aim of the study - to analyze hemodynamic and ergometric parameters of the heart according to veloergometry (VEM) data, lipid composition of the blood and to evaluate anthropometric data in patients with stable coronary artery disease depending on the number of coronary arteries (CA) affected.

Material and Methods. The study involved 62 patients with stable coronary heart disease with functional angina (FC) III with heart failure (HF) IIA FC III with preserved left ventricular ejection fraction (LVEF). Among the surveyed men were dominated by 52 persons ( $83.9 \%)$. The mean age of the patients was (61.2 \pm 1.2$)$ years. Clinical groups are divided into subgroups depending on the number of affected CA: in 16 (25.8\%) patients according to the coronary angiography (CAG) revealed a single-vessel lesion, and in 46 (74.2\%) patients - a multi-vessel.

Results. Coronary and myocardial reserves and myocardial contractility according to VEM were shown to be reduced in both observation subgroups, however, such changes were observed in the case of two or more CA ( $p<0.05)$. According to anthropometric indices, body mass index (BMI) and waist circumference exceeded the normative value in 42 (67.7 \%) patients $(p<0.001)$, and in patients with multivascular CA the data of patients with the affected one CA $(p<0.05)$ prevailed.

The amount of total cholesterol (TC), triglycerides (TG), low and high density lipoprotein cholesterol (LDL cholesterol, HDL cholesterol) in the serum were significantly different in both groups of patients $(p<0.05)$.

KEY WORDS: angina pectoris; coronary arteries; physical activity; lipids; obesity. 